\title{
Changes in the Recording of Cash-Based Accounting Methods to Accrual Base
}

\author{
Dian Islamiatus Sa'diyah ${ }^{1}$, Indrawati Yuhertiana ${ }^{2}$ \\ 1,2 Universitas Pembangunan Nasional "Veteran", Indonesia \\ Email:dianislamiatus@gmail.com ${ }^{1)}$,yuhertiana@upnjatim.ac.id
}

\begin{abstract}
This study aims to determine changes in public sector accounting from cash basis to accrual basis and which one is better than the two bases. This research uses a qualitative method through literature study that combines a number of reliable data sources such as journals, books, articles, legislation, research results and those relevant to the problem under study, where 12 of the 42 articles were selected and published between the 2013-2018 period. The change in cash basis reform towards accruals consists of 3 phases, namely the pre-autonomy era, the transition era and the post-regional autonomy era. Of the two bases, the accrual basis is better because the accrual basis produces more transparent accounting reports for the sake of realizing good governance.
\end{abstract}

Keywords: Accounting Changes, Accounting Reforms, Cash Basis, Accrual Basis

\section{Introduction}

Of course, changes must be made to lead to changes for the better, which is called reform. The Indonesian government did feel the reforms, where Indonesia experienced a slump in economic activity in 1997. In 1998, the Indonesian nation wanted to change because the Indonesian people were not satisfied with their lives, both from economic, political, legal and social aspects. Likewise in accounting, of course you need to change for the better. Change for the better can also be realized by a government system that is clean, accountable, transparent and credible. (Yuhertiana, Satrio \& Hamzah, 2016) Every change requires a long and tiring process stage, changes need physical infrastructure, supporting regulations, information systems, skilled human resources and the most important thing, namely the desire and support of the leadership to start this transformation process. (Langelo, Saerang and Alexander 2015) Good governance requires changes in government accounting because the accounting process provides financial information to all parties. Accounting changes must be based on a strong foundation, namely the existence of SAP. Government accounting reform (Suryanto, 2018) is an accounting reform which is a process of transition from a traditional system to a modern system. Accounting with the traditional system basically adopts cash-based accounting with single records, while modern accounting adopts an accrual basis using multiple records. The cash basis is a recording method that can identify transactions or recognize transactions based on whether cash has actually been received or not, while the accrual basis system is a recording method that can acknowledge transactions even though new cash can enter or leave in the future or not. the occurrence of cash receipts and disbursements.

When the government uses the traditional accounting system, transactions in the economic aspect have an influence on the amount of cash recorded at the recipient and on economic transactions. (Abdul Halim in Suryanto, 2018) In a traditional system, economic agreements that cause an increase in cash will be recorded in the cash proceeds, and transactions that cause a decrease in cash will be recorded in expenditures. Basic accounting is an accounting principle where in order to determine the determination and reporting of an agreement in a 
financial report (Rahayu, 2015). Cash-based accounting is a very simple method, so that the information on assets and liabilities presented is generally very limited, so it is considered inefficient. Simanjuntak in Ferryono \& Sutaryo, (2017) The cash basis of the accrual system is the basis of accounting to develop Indonesia in its transition to a full accrual system in which income, expenses and financing in the LRA are recognized using the cash basis, and the accrual system is used to identify liabilities, assets and equity in assets on the balance sheet. Meanwhile (Ministry of Finance in Ferryono \& Sutaryo, 2017) that cash basis to accrual basis embodies a strategy advanced by Indonesia in order to provide a financial report submitted to UUKN and aligned with conditions in Indonesia.

Since the emergence of PP No.71 of 2010, where this regulation made the country of Indonesia start a period of changes in accrual-based accounting where this basis has become the benchmark by Law No.17 of 2003 article 36 concerning the measurement and recognition of accrual basis income and expenditure regulations which are realized at the latest in time five (5) years. Financial reports obtained from the application of accrual-based SAP (Praditha, 2015) Compared to accrued costs, accrual-based SAP aims to provide better benefits to stakeholders/decisions (users and supervisors of government financial reports). The application of this accounting standard aims to improve the quality of financial reporting in the central and local governments, this can be the basis for government financial information for decision making in government and there will be hopes for the implementation of accountability and transparency in financial reporting. The commitment accounting system can also be used as a basis for decision making by management, where these decisions can be used to control an organization's budget. The aim of this literary review is to identify how accounting reforms from the cash basis to the accrual basis, and preferably the two bases.

\section{Literature Review}

\subsection{Accounting Reform}

Reform is a change made for a better purpose. In carrying out a better goal, a government must have an accounting standard, where the government accounting standard is initially cash based to accrual basis, this has been since the emergence of Government Regulation No.71 of 2010 concerning the Accrual-based Government Accounting System. With the enactment of Law Number 17 concerning State Finances in 2003, government accounting reform is gaining momentum. The law makes Government Accounting Standards (SAP) the basis for financial reporting of government agencies. The 2004 Law on National Financial Supervision and Accountability 15 reinforces this. Compared with accrued expenses, the financial statements that are defined based on the accrual system of implementing SAP are designed to provide better benefits to stakeholders (users and government financial report auditors).

\subsection{Accounting Records}

In accounting records basically use single entry (single entry bookkeping). Over time the accounting system adapted double entry bookkeping. (Yandari \& Rofik, nd) Single entry bookkeping (single recording) is used for the bookkeeping process which has easy and practical reasons, over time with increasing demands for the creation of good public governance which is the emergence of a demand for transparency and accountability in managing a public sector finance for the change from a single entry system to a double entry which is seen as a matter of improvement that is fast enough to be implemented. 


\subsection{Cash Bases}

Cash basis is a recording method that can identify or influence a transaction or recognize a transaction based on whether the cash has actually been received or not for the recognition of expenditures, financing and income. This cash basis records financial activities when cash is received, for example a company sells a product but does not receive payment, so it does not record sales revenue for the product (Trihani, 2018) If cash is received, new transactions will be recorded on an "accrual basis", which applies. for transactions where both methods will affect the financial statements; If an accrual basis is used, selling to companies on credit will increase the accounts receivable, if the cash basis is used, receivables will be lower than the actual amount issued.

\subsection{Cash Basis Towards Accrual}

Simanjuntak (2005) explains that the cash to accrual system is the basis of accounting established in Indonesia during the transition process, and the full accrual system is created using the cash payment system, recognizing revenue and finance in the budget realization report, as well as accrual basis recognition as well as for the recognition of liabilities. Itself, assets and equity are on the balance sheet. Cash-based accounting exemplifies accruals as part of the transition process. Changes in accruals on a cash basis are listed in Appendix I, effective from the date specified, and applicable to each entity; In addition, in Appendix II, cash accrued under SAP is in transition to an entity that is not yet ready to implement SAP on an accrual basis. Apart from changing the SAP basis from cash to accruals, the government also approved the revision of the PSAP which was managed by the Minister of Finance. PSAP can be changed in accordance with the dynamics of national financial management, even so the preparation of SAP reports by KSAP still has to go through the standard process of drafting SAP and needs to receive consideration from the BPK. Changes from the cash basis to the accrual basis experience from various aspects, namely as follows:

1. Measurement and recognition of the cash basis towards the accrual basis

Basically, the application of accrual-based accounting is reflected in an activity/operating information. The benefits of implementing accrual accounting for the government (Suryanto, 2018) through the application of extended information (not just cash-based information) to convey more transparent information related to improving the quality of decision making to the government, and for users of financial reports, if financial reports are provided with accrued expenses, this basis. On the other hand, users of financial statements tend to assess the entity's responsibility to manage all resources, evaluate performance and understand the financial status (cash flows) of the reporting entity. IFAC and PSC show that two modifications are used between the cash system and the accrual system, namely the modified cash system and the modified accrual system.

a. Cash basis

This cash basis is recognized when a transaction is received, this is comparable to the statement by Bastian (2005) in (Suryanto, 2018) that the cash system can record or confirm transactions when cash is received, or if cash does not change in the transaction, it does not need to record transactions.

b. Modified cash basis

The modified cash basis is almost the same as cash-based accounting, where the difference lies in the current year period plus a certain period of time. Financial statements on a modified basis require additional disclosure of certain items, such as on an accrual basis. 
This basis is also recognized when transactions are paid in cash during the period and any receivables and / or accounts that have not been paid at the end of the period.

\section{c. Accrual basis}

Accrual basis, namely recognizing an expense at the time of the transaction, which capitalizes fixed assets and records revenue received when income is earned, besides this accrual basis measurement focuses on measuring economic resources and changes in resources in an entity.

\section{d. Modified accrual basis}

This modified accrual basis is when a transaction is recognized and occurs when the transaction does not occur, and not when cash is paid or received.

2. The technique of recording single entry into double entry

A single recording system can only be recorded at one position in the financial statements, and has nothing to do with one item and another item. In addition, a single recording system is only based on cash, because that basis is the basis of a simple cash basis. Meanwhile, the double recording system is analyzed first by linking the transaction with the accounting equation. Double recording is recorded in two different books because (Suryanto, 2018) each transaction can be recorded directly in two or more different books, therefore it can be said that it is impractical and also inconvenient.

\section{Financial reports}

Financial reports in Indonesia can be produced with an accounting process and without an accounting process (Suryanto, 2018) as follows:

a. Generating reports from accounting processing, starting with identifying transaction certificates, journals, general ledgers, list of ledger balances and compiling reports. What can be audited is the first type of report, and will most likely lead to an unconditional audit.

b. Reports that can be prepared without accounting processing are prepared using information about cash disbursements and receipts and a list of assets at the end of the period. Information about assets, liabilities and equity funds is generated through unstructured information.

In the development of accounting in Indonesia, there are transition phases, namely as follows:

1. The period before regional autonomy

In the phase before regional autonomy, the government administration system was still carried out manually and single entry, because in that period there was no computerized system.

2. The period of regional autonomy transition

In the transition phase of autonomy, local governments mostly use information records for internal and external parties within the local government. (Suryanto, 2018) In 2002 the Minister of Home Affairs issued Kepmendagri No.29 in 2002, modified cash basis accounting and double entry for government financial records were introduced, but during that period there was no governing accounting standard.

3. The period after the regional autonomy transition

In 2001, with the issuance of MAKUDA in Indonesia, it actually implemented accrual accounting. The government issued Law No.17 of 2003 regarding state finances where the law states that the Indonesian government's accounting system has changed to an accrual 
basis, besides that measurement and recognition must be carried out within 5 years after the law is enacted. In this era, there has been a gradual change from the cash accounting system to the accrual system, and the accrual cash system was adopted at the time of preparation of the 2005 financial statements and budget (Suryanto, 2018). Although the cash basis toward accruals still has not applied in totality, this change in cash basis has partly referred to accrual-based accounting practices. (Suryanto, 2018) argues that in SAP based on the accrual system, the transition from cash to accruals to accruals is achieved by referring to the International Public Sector Accounting Standards (IPSAS) and in accordance with SAP regulations. The applicable laws and regulations have been revised to achieve. Therefore, in 2005, the structure of the PP PSAP No. 24 hasn't changed much.

\subsection{Full Accrual Basis}

Changes in accounting reform are very influential in the financial sector where the financial statements used by the parties concerned are required by internal and external parties, therefore the accrual basis is an accounting basis that can meet the demands of those in need. Minister of Home Affairs Regulation Number 64 Year 2013 Article 1 paragraph 10 Accrual basis means that economic transactions or accounting events are confirmed based on the impact of the transactions at the time the transactions occur, are recorded and included in the financial statements, regardless of when the cash is received. The benefits of accrual-based financial statements in PP No. 71/2010 in (Trihani, 2018) are as follows:

1. Provide detailed financial information, especially when measuring government performance in terms of service costs, efficiency and achievement of objectives during the accounting period.

2. Provide a complete picture of the government's financial situation for decision making; and

3. Participate in the best international training in other countries / regions and comply with national financial laws

According to Yuhertiana, Satrio \& Hamzah (2016) this is in line with the accounting principle that the costs incurred are proportional to the benefits received. Even though its application to this basis certainly has obstacles, namely the choice of various valuations, asset reporting and recognition (Zelmiyanti, 2015). In SAP No. 17 paragraph 43 even if cash is not received from the State or Regional General Treasury Account, the accrued revenue base should be recognized when the revenue is earned. (Yuhertiana, Satrio \& Hamzah, 2016) Every change needs a long and tiring process stage, changes need physical infrastructure, supporting regulations, information systems, skilled human resources and the most important thing, namely the desire and support of the leadership to start this transformation process.

Table 1. Comparison of SAP "CTA" and SAP "Accrual Basis"

\begin{tabular}{|l|l|l|l|}
\hline No & Differentiator & SAP "CTA" & SAP "Accrual Basis" \\
\hline 1. & Report Type & 1. LRA & 1. LRA \\
& & 2. Balance sheet & 2. Balance sheet \\
& & 3. LAK & 3. LAK \\
& & 4. CALK & 4. CALK \\
& & & 5. Operational Report \\
& & & 6. Change Report SAL \\
& & 7. Statement of Changes in Equity \\
\hline
\end{tabular}




\begin{tabular}{|l|l|l|l|}
\hline 2. & Income Recognition & $\begin{array}{l}\text { When cash is received in } \\
\text { the State / Regional } \\
\text { General } \\
\text { Account } \\
\text { Treasury } \\
\text { Satker) }\end{array}$ & $\begin{array}{l}\text { 1. Income in LO, if there are rights } \\
\text { arising and / or there is a flow of } \\
\text { economic resources }\end{array}$ \\
\hline 3. & Expenditure Recognition & $\begin{array}{l}\text { When cash is issued from } \\
\text { the State / Regional } \\
\text { General } \\
\text { Account } \\
\text { (Except BLU Satkel) }\end{array}$ & $\begin{array}{l}\text { 1.Expense-LO, } \\
\text { consumption of the asset, the } \\
\text { liability arises and the economic } \\
\text { benefits decrease } \\
\text { 2.Shopping-LO, at the time the cash } \\
\text { goes out / payment from the State / } \\
\text { Regional General Treasury Account }\end{array}$ \\
\hline
\end{tabular}

Source: Yafie (2013)

\section{Method}

This research method uses qualitative type research through literature study, where this research aims to provide an analysis or an overview of the research results by combining a number of reliable data sources such as journals and laws \& regulations in Indonesia that are relevant to the problem under study. Sources of data from the writing of this study are Research gate and Google Scholar. From this study, it was obtained from 42 journals, 5 regulations in Indonesia, 2 books selected as the basis for literature sources related to the keywords "Accounting Changes", "Accounting Reforms'," Accrual Basis "and" Cash Basis ". From these criteria which are used as the basis of literature, it produces 12 selected journals, 5 regulations in Indonesia and 2 books, so that it can provide a theoretical introduction in research on changes in the cash basis to accruals. The analysis was carried out by reviewing journals published between 2013 and 2018. The purpose of this study was to review a literature on changes in the cash basis towards accruals and which one is better for the government in Indonesia.

\section{Findings and Discussions}

Based on the literature study that the cash basis accounting reform towards accrual basis is implemented in stages, namely the existence of 3 phases, namely in the period before autonomy, transition and post regional autonomy. Many changes have occurred in the techniques, recording and application of Indonesian government accounting. From these two bases, we can see that the cash basis is known for its simple recording, but the accrual basis is superior because the accrual basis produces more transparent and accountable accounting reports in realizing reliable, good, clean and accountable accounting reports that can also push the way good governance. Therefore, accountability can play a very important role in preventing institutions from misusing public facilities, facilities and budgets (Idawati \& Eleonora, 2020).

\section{Conclusions and Suggestions}

In this case, the explanation above can be said that changes in cash basis accounting towards accruals are experienced by the government, where the government carries out these reforms for the better. Changes in the reform of accounting records in Indonesia, namely the cash basis to the accrual basis, this means that the accrual basis requires a lot of changes in 
terms of aspects of human resources and a modern technology, therefore accrual-based accounting records are carried out gradually through a transition process. These reforms can lead to transitions in an era, where this era occurs in 3 stages, namely the phase before autonomy, transition to autonomy and post-autonomy, besides that each stage of development is marked by the results of the presentation in the financial statements. This reform change was carried out in order to create an accountability accounting report presentation in realizing good governance in Indonesia.

\section{References}

Bastian, Indra. 2006. Sistem Akuntansi Sektor Publik, Edisi 2, Jakarta : Salemba Empat

Erlina, S. M., Rambe, S. A., \& Rasdianto, M. A. (2015). Akuntansi Keuangan Daerah Berbasis Akrual Berdasarkan PP No. 71 Tahun 2010 dan Permendagri No. 64 Tahun 2013. Jakarta: Salemba Empat.

Ferryono, B., \& Sutaryo, S. (2017). Manfaat Akuntansi Basis Akrual dan Akuntansi Basis Kas Menuju Akrual dalam Pengambilan Keputusan Internal Pemerintah Daerah. Jurnal Dinamika Akuntansi Dan Bisnis, 4(2), 143-158. https://doi.org/10.24815/jdab.v4i2.6797

Idawati, W., \& Eleonora, L. (2020). Penerapan Sistem Pengendalian Intern dan Akuntabilitas Keuangan dalam Mewujudkan Kualitas Laporan Keuangan. EQUITY, 22(2), 153-172.

Indonesia, R. (2003). “UU No. 17 Tahun 2003 Tentang Keuangan Negara.” Zitteliana.

Komiter Standar Akuntansi Pemerintahan. 2020. Pernyataan Standar Akuntansi Pemerintahan. Jakarta

Langelo, F., Saerang, D. P. E., \& Alexander, S. W. (2015). Analisis penerapan standar akuntansi pemerintahan berbasis akrual dalam penyajian laporan keuangan pada pemerintah kota bitung. Jurnal EMBA: Jurnal Riset Ekonomi, Manajemen, Bisnis dan Akuntansi, 3(1).

Praditha, R. (2015). Reformasi Akuntansi : Mengapa Accrual Basis Lebih Baik? 221-225.

Rahayu, Y. (2015). Reformasi Sistem Akuntansi Cash Basis Menuju Sistem Akuntansi Accrual Basis. Jurnal Ecodemica: Jurnal Ekonomi, Manajemen, Dan Bisnis, 3(1), 348-354. http://ejournal.bsi.ac.id/ejurnal/index.php/ecodemica/article/view/66/43

Republik Indonesia. (2010). Peraturan Pemerintah nomor 71 tahun 2010 tentang SAP.

Republik Indonesia. (2013). Peraturan Menteri Dalam Negeri Nomor 64 tahun 2013 tentang Penerapan Standar Akuntansi Pemerintahan Berbasis Akrual Pada Pemerintah Daerah.

Republik Indonesia. (2004). Undang-Undang Nomor 15 tahun 2004 tentang Pengendalian dan Pertanggungjawaban Keuangan Negara.

Sartika, D., Vezalin, F., \& Ilyas, A. (2019). Implementasi Standar Akuntansi Pemerintah Berbasis Akrual (Studi Kasus Pada BPKAD Kota Padang). Jurnal Ekonomi dan Bisnis Dharma Andalas, 21(2), 165-177.

Simanjuntak, B. H. (2005). Menyongsong era baru akuntansi pemerintahan di Indonesia. Jurnal Akuntansi Pemerintah, 1(1), 9-18.

Suryanto, S. (2018). Tinjauan Atas Reformasi Akuntansi Pemerintahan Di Indonesia. Jurnal Agregasi: Aksi Reformasi Government Dalam Demokrasi, 6(2). https://doi.org/10.34010/agregasi.v6i2.1140

Trihani, I. (2018). Analisis Manfaat Basis Akrual dan Basis Kas Menuju Akrual Dalam Pengambilan Keputusan Internal Pemerintah Daerah. Journal FE Univeristas Negeri Padang. 
Yafie, M. D. (2013). Penerapan Basis Akrual pada Standar Akuntansi Pemerintahan Indonesia. Jurnal Akuntansi AKUNESA, 2(1).

Yandari, A. D., \& Rofik, M. (n.d.). Behavior Accounting As a History: Perspective Single. 07(01), 9-16.

Yuhertiana, I., Satrio, M. D., \& Hamzah, A. (2016). Implementasi Standar Akuntansi Pemerintah Berbasis Akrual di Kabupaten Jombang. Jurnal Akuntansi Dan Keuangan, 18(1), 59-70.

Zelmiyanti, R. (2015). Perkembangan Akuntansi Berbasis Akrual pada Sektor Pemerintah di Indonesia. JRAK: Jurnal Riset Akuntansi dan Komputerisasi Akuntansi, 6(1), 68-72. 